\title{
A Review of Value Added in Nigeria's Pre and Post-SAP Agricultural Sector: Background and Issues
}

\author{
${ }^{*}$ Ogujiuba Kanayo ${ }^{1}$, Stiegler Nancy ${ }^{1}$, Ogbonnaya Ufiem Maurice ${ }^{2}$ \\ ${ }^{1}$ University of Western Cape; Cape Town-South Africa \\ ${ }^{2}$ National Institute for Legislative Studies, National Assembly, Abuja - Nigeria \\ *kannyog@gmail.com
}

\begin{abstract}
In spite of the growing importance of oil, Nigeria has remained essentially an agrarian economy, with agriculture still significantly contributing to its Gross Domestic Product. However, the potentials of the agricultural sector to contribute to economic development in Nigeria have varied widely in the last two decades. This variation appears to be correlated to the nature of the political and economic regimes that exists. There were indications of some moderate output increase following the introduction of SAP. But, it is not yet certain whether the extent of deregulation policy currently being pursued by the Government and the preliminary outcome has elicited the desired response. One of the indications of the adverse development is the diversion of scarce foreign exchange from financing capital and intermediate imports to paying for food imports. Successive governments have experimented with various options in the promotion of agro-based industries, import substitution, promotion of specific sectors and specific areas. The outcome is an imbalance growth of various sub-sectors in the sector, poor capacity utilization, eroded competitiveness of local manufacturers and uneven playing field within the country. This paper basically reviews and analyzes the components of Nigeria's agricultural sector, its contributions to economic development, and strategies adopted within the sector before and during the Structural Adjustment Program. It recommends that providing the right policy framework/enabling environment and incentives for private sector investment in the sector enshrined in the new economic blue print'Transformation Agenda' could be a viable option for revitalizing the sector.
\end{abstract}

Key Words: Agriculture, Economic Development, Gross Domestic Product, Structural Adjustment Program

\section{Introduction}

In spite of the growing importance of oil, Nigeria has remained essentially an agrarian economy, with agriculture still accounting for significant shares in Gross Domestic Product (GDP) as well as employing about 70 per cent of the labour force (Momor, 2012). Available data show that at independence in 1960 the contribution of agriculture to the GDP was about 60 per cent, which is typical for developing agrarian nations (Omofema, 2007). Estimates indicate that about 75 percent ( 74 million hectares) of Nigeria's total land (98 million hectares) is arable and about 40 per cent of this is cultivated - leaving the remaining 60 per cent of arable land idle. The United Nations Food and Agriculture Organization rates Nigeria's farmland from low to medium in productivity, but notes that most of the country's cultivable land would have medium to good productivity, if properly managed. The principal export crops are cocoa and rubber, which together account for nearly 60 percent of non-oil merchandise exports (Ugwu \& Kanu, 2012; Amassoma, Nwosa \& Ofere, 2011).

\section{Figure 1: The overall contribution of Agriculture to overall Gross Domestic Products [GDP]}

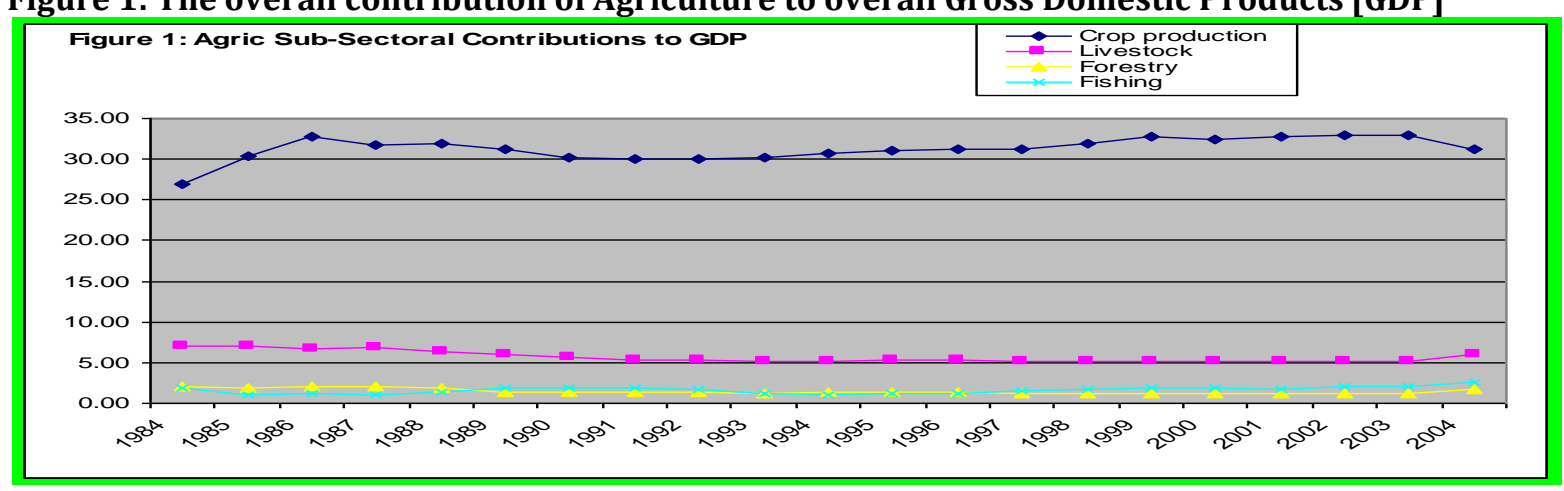

Source: Calculated from Statistical Bulletin and CBN Annual Report and Statement of Account 
The table above shows that crop production has consistently maintained the lead. The agricultural history of Nigeria is intertwined with its political history. This can be accessed from the pre-colonial, colonial and post-colonial periods. Before the British conquest the pre-colonial society strived on agriculture as the main stay of the traditional economy. The period of the colonial administration in Nigeria, $1861-1960$, was punctuated by rather ad hoc attention to agricultural development. During the era, considerable emphasis was placed on research and extension services with export crops being emphasized for raw materials purposes. The role of agriculture in the macro economy and in structural change dominated the policy agenda of the 1980s, as growing debt burden, a slowdown in the world economy and a collapse of commodity prices forced developing countries including Nigeria to undergo wrenching structural policies (the Structural Adjustment Program). In 1986, the process of economic deregulation in Nigeria commenced with the adoption of the Structural Adjustment Program (SAP) and sectoral policy reforms. The emerging enabling environment has since played a dominant role in attempting to get agricultural incentives right in Nigeria. It was expected that the multiplier effects of a structural transformation in the sector would feed back to the economy ultimately. However, it is not yet certain whether the extent of deregulation so far and the preliminary outcome has elicited the desired response. Yet, there is the urgent need to sustain agricultural growth beyond the current rates if the challenges confronting it are to be overcome. This is the central focus of the paper. The main objective is to assess the output growth in the sector during and after the structural program, identify the prospects and possible policy solutions within the context of the new economic blue-print - 'Transformation Agenda'.

\section{Overview of Nigeria's Agricultural Sector}

Nigeria's total land area is 92.4 million hectares. Of this area 91 million hectares is adjudged to be suitable for cultivation. Approximately half of this cultivable land is effectively under permanent and arable crops, while the rest is covered by forest wood land, permanent pasture and built up areas. Among the States which have the most abundant land areas are Niger and Borno with 7.6 million hectares and 2.8 million hectares respective (Njoku, 2002; Federal Ministry of Agriculture, 2011). In 1996, a total of 33 million hectares were cultivated to crops generally; out of which 17.7 million hectares were for staples and 4.9 million hectares were for industrial crops. Agriculture crops in Nigeria are grouped into cereals ${ }^{1}$, root and tuber crops $^{2}$, grains legumes and other legumes ${ }^{3}$, oil seeds and nuts ${ }^{4}$, tree crops $^{5}$ and vegetables and fruits. ${ }^{6}$ Cattle rearing have been given the greatest prominence in discussions of Nigeria's livestock industry ${ }^{7}$. The country's cattle territory is essentially in the Sudan Savannah where the limiting factors are the amount of water supply available as one moves north from the Middle Belt or Guinea Savannah towards the Sahara and the existence of tsetse-fly infested forests to the south. These two lesser areas contain the remaining 10 per cent of the country's cattle population. The cattle industry accounts for about 70 per cent of the country's population of sheep and goats that have adapted to the ecological constraints. In the Guinea Savannah and Southern forest zones, there is found the remaining 30 per cent made up of the indigenous dwarf breeds of sheep and goats. Various exotic breeds of pigs are found in different areas of the country. All over the country, there is a very large population of poultry, especially the local breeds reared under free-range conditions. Commercial production of poultry and pigs takes place in various states of the federation (Ikhatua, 2000; Njoku, 2002).

\footnotetext{
${ }^{1}$ Guinea corn, "sorghum spp", millet, maize "zea mays", and rice "oryza sativa

${ }^{2}$ cassava "Manihotesculenta", yam "Dioscoreaspp", cocoyam, and potatoes (sweet and irish

3 cowpeas "Vignaunguiculata", locust bean "Parkiaclappertoniana", soyabean "Glycine max" and other beans such as groundnut "Arachishypogeae", pigeon pea "Cajanuscajan", bambara nuts "Voandzeia subterranean

${ }^{4}$ melon "Cococynthyscitrullus", benniseed "Sesannumorientae or S indicum", kolanut "Cola nitida or C. acuminata", coffee "Coffee Arabic

${ }^{5}$ cocoa "Theobroma cacao", oil palm "Elaeisguineensis" and rubber "Heveabrasiliensis

6 vegetables: onions "Allium cepa", African spinach "Amaranthusspp", Indian spinach "Basellarubra", Pumpkin "cucurbitapepo", Sweet pepper "Capsicum annum", Hot pepper "Cinetumafricanum", Water leaf "Talinumtriangulare", Carrot "Daucuscarota" and Lettuce "Lactuaca sativa"; fruits: pineapple "Ananascomosus", Pawpaw "Carica papaya", Mango "Magniferaindica", Banana/plantain "Musa spp", Citrus "Citrus spp" and Guava " psidiumguajava

7 This main cattle territory contains about 90 per cent of the country's cattle population. The two other cattle-producing areas are the southern forest zone where the Muturu cattle which is tolerant to typanosomiasis is found, and the Guinea Savannah where the Ndama cattle and crosses of Muturu and northern Zebu cattle are found.
} 
Fishery in Nigeria is mainly done by the artisan sector. The coastal and brackish waters constitute the major areas of production, followed by inland rivers and lakes. No attempt has yet been made at separating the production into coastal and brackish water sources because the species of fish utilized are closely similar and also because it is difficult to separate the fishing communities into those that operate at sea and those that fish in the lagoons, creeks and other brackish water environments. Production from aqua culture is still low. Production from industrial fishing, which comprises the commercial trawlers, is also low compared to the artisan. The demand for fish in Nigeria today is certainly greater than the total production from her domestic sources. Thus imports account for about 50 per cent of fish consumption in the country.

Contribution of the Sector to Economic Growth and Development: Agriculture was the mainstay of the economy prior to the oil boom of the 1970s. However, the sector was expected of the sector to play many roles towards development, which includes provision of adequate food, a major source of employment, foreign exchange, raw materials, etc among others. We would consider the contributions along market, product and factor contributions.

A) Market Contribution: There are two basic considerations in discussing a substantial market contribution. One is the purchasing power of the sector which depends on the rate of modernization of the economy and the sector. Thus the slow growth of the sector and low pace modernization has constrained the sector's market. Due to this fact, the sector has failed. The second consideration is the ability of the industrial sector to respond to the demand of agriculture, which is absolutely lacking in the sector ${ }^{8}$.

B) Product Contribution: An examination of the share of the sector in GDP, its contribution to the food needs and provision of raw materials would give a fair picture of the product contribution. Obviously, the share to GDP has been predominant more especially in the 1960s. The table 1 below shows the composition of contribution for the period $1960-1999$.

Table 1: Share of Agriculture in the GDP

\begin{tabular}{|c|c|c|}
\hline $\begin{array}{l}\text { Period } \\
\text { Average }\end{array}$ & Year & Share of Agriculture in GDP $\{\%\}$ \\
\hline $1960-1964$ & & 62.3 \\
\hline $1965-1969$ & & 53.8 \\
\hline $1970-1974$ & & 39.1 \\
\hline $1975-1979$ & & 23.3 \\
\hline $1980-1984$ & & 23.3 \\
\hline $1985-1989$ & & 37.2 \\
\hline $1990-1994$ & & 37.9 \\
\hline $1995-1999$ & & 38.6 \\
\hline $1999-2003$ & & 37.2 \\
\hline 2004 & & 34.8 \\
\hline
\end{tabular}

Source: Computed from CBN: Annual reports and Statement of Accounts various issues

In the 1960s, the sector maintained a share of about 56 per cent on the average, which declined considerably to 25 per cent in the 1970s. This decline continued in the 1980swith a little rising towards the end of the decade. The share has relatively remained stable but not impressive. It goes without saying that the growth rate of the 1960s for the sector is absolutely necessary to reposition the sector as the engine room for industrial growth in the country. The index of Agricultural Productivity by type of activity shows the impact of the oil boom on the sector. The aggregate index had a value of -0.6 per cent growth rate between 1970 and 1985, 8.8 per cent growth rate between 1986 and 1993 and 3.1 per cent between 1994 and 2001. The increase came during the Structural Adjustment era as a result of emphasis on the sector as an alternative to oil revenue and the ability of the sector to serve as a major catalyst in

\footnotetext{
${ }^{8}$ It becomes clear that the only way for an improvement is to enhance the linkage between agriculture and the industry.
} 
jump starting the non-functional manufacturing sector. This period witnessed a boom for staples as it moved from -2.4 per cent between 1970 and 1985 to 12.8 per cent during the reforms. This was the trending for almost all the activities within the sector, but could not be sustained. The sharp and continuous decline is evident with the value of the aggregate index for the period 1994 to 2001. Table 2 below shows the dismal performance of major commodities that add up to the sector's contribution to GDP over time. This raises pertinent questions, what is the reason behind the continuous decline of the commodities? What are the determinants of aggregate output in the sector? What does the future portend for the sector in Nigeria, giving the instability of the oil sector?

Table 2: Output of major Agricultural Commodities \{'oootonnes\}

\begin{tabular}{|c|c|c|c|c|c|c|c|c|c|c|c|}
\hline & $\begin{array}{l}\text { Cotton } \\
\text { seed }\end{array}$ & $\begin{array}{l}\text { Palm } \\
\text { kernel }\end{array}$ & $\begin{array}{l}\text { Palm } \\
\text { oil }\end{array}$ & $\begin{array}{l}\text { Groundnut } \\
\text { oil }\end{array}$ & Cocoa & Coffee & Rubber & Maize & Sorghum & Wheat & Tobacco \\
\hline 2000 & 353 & 629 & 860 & 2390 & 170 & 200 & 275 & 6491 & 8854 & 56 & 19 \\
\hline 2001 & 359 & 632 & 872 & 2361 & 171 & 202 & 279 & 6592 & 9408 & 54 & 20 \\
\hline 2002 & 379 & 645 & 884 & 2375 & 172 & 205 & 284 & 6698 & 9687 & 59 & 21 \\
\hline 2003 & 398.8 & 690.4 & 949.4 & 2560.7 & 185.5 & 220 & 304.4 & 7185.1 & 10322.2 & 61 & 21.7 \\
\hline 2004 & 429.2 & 745.5 & 1025.8 & 2815.6 & 202.6 & 239.3 & 328.9 & 7908.8 & 10895.5 & 66.1 & 21.9 \\
\hline
\end{tabular}

Source: CBN: Annual reports and Statement of Accounts and CBN Statistical Bulletin 2004

The decline shown in Table 2 makes it implicit that crop production which is contributing about 70 per cent of the output in the sector is at the brink of precipice after showing positive sparks during the structural adjustment programs. However, the overall contribution of the sector to food could be measured via the volume as well as value of food imports. Table 3 shows the value of food imports as well as it's percentage to total imports, between 1962 and 1999.

Table 3: Value of Food imports and \% of total imports

\begin{tabular}{lll}
\hline Period \{yearly average\} & Food import $\{\mathbf{N m}\}$ & \% to total imports \\
\hline $1962-1954$ & 44.0 & 9.9 \\
$1965-1966$ & 48.8 & 9.2 \\
$1967-1970$ & 31.0 & 7.8 \\
$1971-1973$ & 103.2 & 9.4 \\
$1974-1976$ & 298.1 & 11.1 \\
$1977-1980$ & 903.7 & 11.2 \\
$1981-1983$ & 1586.3 & 15.8 \\
$1984-1985$ & 891.9 & 17.8 \\
$1986-1987$ & 2214.5 & 10.2 \\
$1988-1989$ & 1970.1 & 7.2 \\
$1990-1994$ & 5393.5 & 8.9 \\
$1995-1999$ & 6412.5 & 14.0 \\
$2000-2003$ & 6820.93 & 17.9 \\
2004 & 1978.03 & 12.1 \\
\hline
\end{tabular}

Source: CBN: Annual Statement of Accounts of various years

Absolute food imports have been unstable and have risen overtime. Before 1974, food bill constituted less than 10 per cent of total import bill. However, the bill has since risen. It is obvious that the sector played a significant role until the 1970swhen the imports became intensified. The decline in the domestic food supply is evident in the volume and composition of food imports as well as the increased size of financial resources committed to the importation of food over time. With only about N44 million spent on food imports per year between 1962 and 1964 the amount rose to about N2.2 billion per year between 1966 and 1967. Another way of looking at the trend is the proportion of the import bill devoted to food imports. It was only 7.8 per cent per year in the 1968-70 periods. It rose to about 18 per cent from 1984 to 1985 and was actually raised to 21 per cent in 1984 . It is observed that the declining trend in the supply of food for the population had adversely affected the development trend in the economy. One of the indications of the adverse development is the diversion of scarce foreign exchange from financing capital and intermediate imports to paying for food imports. It appears this has given the present government so much concern as to embark on a reform program to restructure the economy. 
Foreign Exchange: The agricultural sector was a major earner of the country's foreign exchange before the oil boom, while the other sectors contributed only a small proportion. However, the foreign exchange contribution from agriculture seems to have witnessed the most dramatic decline. The absolute decline is clearly demonstrated in Table 4 which presents the volume of the major agricultural export crops from 1959 to 1989 . Of the given major crops, only cocoa, and to a much lesser degree palm oil and rubber, have remained consistent in being retained in the export list throughout the period, even then at a declining rate. The other two, groundnuts and palm kernels are no longer exported. It is important to note that Nigerian groundnuts accounted for 30 per cent of the world export of groundnuts before the oil boom and that Nigeria was one of the largest exporters of palm kernels until the midd-1960s (World Bank, 1974).

Table 4: Volume of Principal Agricultural Exports (1959-2000) (000 Tons)

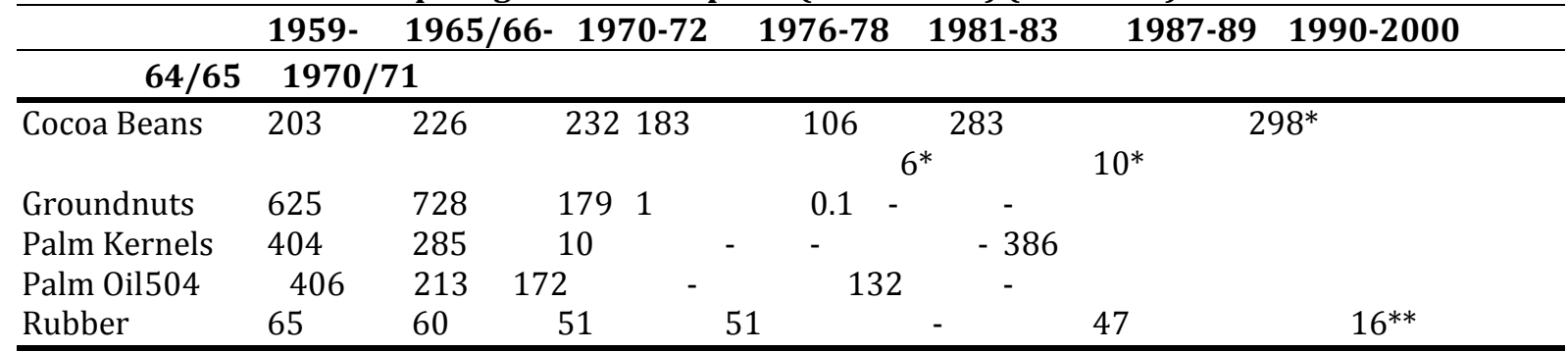

*Processed Cocoa Butter **Palm oil Products

Sources: 1. World Bank, Nigeria: Options for Long Term Development, John

Hopkins, University Press, Baltimore, 1974.

2. Central Bank of Nigeria, Annual Reports and Statements of Accounts, Lagos (various issues).

a) Factor Markets: There are two major sources of factor contribution from the sector, namely capital and labour. The potential of the sector as main source of capital formation is not in doubt. The marketing boards were established to actualize this potential. This engaged the attention of the boards from inception till they were abolished in 1986. The funds generated were completely mismanaged. The role of the sector in facilitating the release of labour to other sectors of the economy could be regarded as double edged as in the case of many developing countries. The sector is still expected to perform the function of an employer to the growing labour force in the economy. There is evidence that the agricultural labour force has been moving out of the sector at a faster rate than could be absorbed by the non-agricultural sectors. This has contributed significantly to the unemployment problem in the country. Although accurate statistics are difficult to obtain, there is abundant evidence that urban employment is very high and has been growing over the years as a result of rural-urban migration. The industrial sector is not adequately equipped to absorb the rate of labour mobility. In essence, this factor compounds the already high unemployment situation in the country.

Policy Measures for the Sector before the Structural Adjustment Program: One way to examine the policies and programs in the agricultural sector is to do it without breaking them into distinct periods. One merit of this approach is that a program that was in operation during two or more of the periods may have to be repeated for the different periods. Many of the policies on agriculture have these characteristics. In general, the major policy measures adopted before SAP ranged from the provision of financial resources for agricultural infrastructures, input supply/delivery, management training, mechanization, to direct involvement in agricultural production.

b) Financial Policy Measures: The policy measures under this sub-heading are discussed below:

Agriculture as a "Preferred" Sector9: For the purposes of funding, agriculture is accorded high priority by government. This is reflected in its classification as a "preferred" sector hence the Central Bank of Nigeria directed all commercial and merchant banks to give priority to agriculture in their allocation of loans and advance (credit guideline). Usually, the sector takes preference over some other sectors in terms of volume of loans as well as the ease of granting such loans.

\footnotetext{
${ }^{9}$ However, with the provision of the policy, the banks are mandated to discharge that responsibility. This policy had
} contributed to the improved financing of agricultural activities. 
Agricultural Credit Guarantee Scheme Fund ${ }^{10}$ (ACGSF): Agricultural Credit Guarantee Scheme Fund (ACGSF) is jointly financed by the Federal Government and the Central Bank of Nigeria (CBN). This was to be achieved by providing a guarantee of $75 \%$ of the value of principal and interest outstanding for such loans granted by the banks. The guarantee has a maximum of N50, 000.00 loan for an individual and N1 million for a corporate body.

Nigerian Agricultural and Cooperative Bank Limited (NACB): Nigerian Agricultural and Cooperative Bank Limited were established in 1973 for the purpose of providing financial resources for all types of agricultural activities. It was mandated to grant loans for all types of production by individual farmers, state owned institutions such as corporation for on-lending to farmers' groups and cooperative societies. In particular the bank sought to achieve the following goals:

c) increasing the production

d) increasing the production of agricultural raw materials for the use of domestic industries and for export

e) enhancing rural employment opportunities

f) Improving the standard of living of the rural population.

In addition, the bank is to assist state governments, cooperative banks and other credit agencies in the formulation, organization and administration of agricultural credits, carrying out research aimed at improving distribution and recovery of loans, improving the performance of lending agencies and providing consultancy services to clients.

\section{Major Agricultural Programs}

Many agricultural programs have been implemented by the various Nigerian administrations. Out of these, four of the major ones are examined in this section.

Operation Feed the Nation (OFN): Operation Feed the Nation (OFN) was launched in 1976 with the main objective of mobilizing the nation towards self-sufficiency in food production. The goal was to be achieved by encouraging all the sections of the society to grow their own food. This includes civil servants, teachers, the police, the army, etc. The measures adopted included massive distribution of heavily subsidized farm inputs, liberalization of bank credits to agriculture, establishment of new commodity boards to cover the major crops including food crops, fixing or guaranteeing minimum prices, construction of stores and warehouses, provision of cold stores for preservation of perishable food items and the establishment of agro-service centers. In addition, government provided essential inputs for farmers and engaged in other promotional activities. In spite of the huge investment committed to the scheme, its success has been described as merely psychological. It created some awareness of food crisis in the nation and also the need to grow more food. The Green Revolution Program (GRP) of the 19791983 civilian administration built on the foundation of the OFN.

National Accelerated Food Production Plan (NAFPP): The Scheme, a joint program among the Federal and State Governments as well as the farmers, was designed to accelerate the production of grains such as maize, rice, guinea corn, millet, cow-peas and root crops. This was to be achieved through the introduction of high yielding seed varieties, fertilizers, insecticides, herbicides, credit facilities, marketing, storage, storage and processing facilities. Various research institutes were to be transferred to extension staff for trial on some farmers' land in small plots before they could go into mass adoption stage. An important advantage of the scheme is that farmers were involved in all the stages of the production package. Therefore, the technologies were expected to be adopted with relative ease. This advantage notwithstanding, it suffered from inadequate finance, shortage of extension staff and low market price for grains, among other problems.

The Agricultural Development Programs (ADPs): The primary aim of the ADPs is to increase agricultural productivity and incomes of the farmers in the areas of their coverage and thereby increase total food and raw materials supplies for the rapidly growing population and the agro-based industries. This objective is to be attained by providing a package of essential inputs as well as an efficient delivery system through the farm service centers. Some of the main features of the ADPs include the improvement of infrastructures within the project areas through the construction of feeder roads, dams for providing

${ }^{10}$ It was established in 1977 by a Federal Government Decree with the sole objective of inducing commercial and merchant banks to grant loans more readily to farmers, thereby creating easy access to such loans by farmers. 
irrigation water, provision of extension and marketing services, provision of credit facilities to farmers, and the provision of a base for the improvement of health and other social services in the project area. A long-term objective of the ADPs is to create a prosperous virile and efficient agricultural industry to reduce the migration of people from the rural areas into the cities. The program was also targeted towards Integrated Agricultural and Rural Development. Some of the problems that have constrained the ADPs in achieving their goals include the following: Finance posted a real problem as both the Federal and State Governments often failed to contribute their counterpart funds regularly. Also, there appears to be some duplication and conflicts between the ADPs and some other agricultural programs which provide similar services. These programs include the River Basin Development Authorities, the State Ministries of Agriculture and Agricultural Development Corporations. Proper coordination would be needed among these programs for government to achieve desired goals and reduce waste.

The River Basin Development Authorities (RBDA): The River Basin Development Authorities (RBDA) was established in 1976 primarily to boost food production in the country. Among the objectives of the authorities are the development of surface and underground water for multipurpose uses, construction of dykes, dams and boreholes for irrigation, development of fish farming and livestock, establishment of large scale seed multiplication livestock and fish, establishment of grazing reserves and agro-service centers. It was assumed that the RBDA had the potential for transforming and improving rural lives by providing food and other basic needs for the people, the more so when they were at the core of the Green Revolution Program during the civilian regime of 1979-1983. Perhaps some of their noticeable achievements are in the areas of land clearing and development, irrigation and the provision of other infrastructures. The government has now removed the direct agricultural production function from their mandate. Instead, they are to concentrate on the harnessing of water resources, irrigation and infrastructural facilities for farmers.

Other Policy Measures: There are some other measures undertaken by the authorities which do not fit perfectly into those that had been discussed thus far. Only two of these will be discussed in this section.

Agricultural Technology (Mechanization): The need for technology, particularly mechanization in agriculture, became much more felt during the oil boom. This resulted from the mass exodus of labour from agriculture into the urban areas in search of alternative employment. The Nigerian agriculture thus became constrained by labour shortage. Consequently a number of measures were put in place to achieve some degree of mechanization in the agricultural sector. These measures include:

a) The establishment of Tractor Hiring Units (THU) by governments. These are units where farmers could hire tractors for specific periods at highly subsidized rates. The major problems with the units had been inadequate number of tractors, the frequent breakdowns and lack of spare parts.

b) The inducement of farmers to purchase their own tractors. This was done through liberalization of import policy on tractors and other agricultural machinery as well as by encouraging farmers and cooperative groups to purchase machinery at subsidized rates while payments were to be made on install mental basis.

c) The mandate given to the River Basin Development Authorities to provide assistance on land clearing to farmers. Thus farmers could take advantage of the services to expand cultivated land with little dependence on labour.

d) The establishment of a National Centre for Agricultural Mechanization (NCAM) established in 1981 to provide solutions to the need for agricultural mechanization. The Centre, which is, perhaps, the most noticeable policy on agricultural mechanization was established to provide answers to the problems of shortage of labour on the farm; the demand for mechanization is likely to continue to increase. However, wide-spread use of tractors and other agricultural machinery is tradition of mixed farming or intercropping which normally prevents the uses of machines during peak periods for weeding, cultivation, ridging, etc. Similarly, the lack of experience by farmers in the operation and maintenance of tractors is another constraint to mechanization. Therefore a training program in operation and maintenance of tractors and other machines is imperative if mechanization is to be achieved. 
The Agricultural and Rural Management Training Institute (ARMTI): Many agricultural programs were launched in the 1970s. These include the Agricultural Development Projects (ADPs), the River Basin Development Authority (RBDAs), etc. For implementation, these programs had relied on expatriate staff. Therefore, a long-term solution to the problem was thought to be in the provision of the required manpower within the country. It was on this premise that the Agricultural and Rural Management Training Institute (ARMTI) was established to be jointly funded by the Federal Government and the World Bank. The main objective of the Institute is to provide training in managerial and supervisory skills for staff at all levels of agricultural and rural management. The ARMTI organizes training for the staff of all sectors of the agricultural industry, federal and state ministries, ADPs, RBDAs, marketing and credit organizations and the local governments. By this training the Institute is expected to improve the effective administration of agricultural and rural development programs and also increase the ability of the industry to achieve the needed change and development.

Impact of the Policy Measures: There is no controversy about the fact that agriculture was the prime mover of the Nigerian economy up to the 1960s. The export crop sub sector was the most developed then given the great attention paid to it by the colonial administration. Also, it was the sub-sector that kept the best record of activities. As we have seen, this positive role of agriculture was not sustained in the 1970s and 1980s. Consequently, the agricultural sector and indeed the economy witnessed a decline which the structural adjustment program was designed to reverse. However, before SAP was put in place the various administrations in the country introduced a variety of policies and implemented series of programs with a view to reversing the trend. It has been suggested (Ojo, 1989) that it would seem logical to place the blame (of declining agriculture) largely at the doorstep of a defective agricultural policy rather than a neglect of the sector's development because of the oil wealth of the 1970s. The reason being that the government was more active in designing and implementing agricultural policies in the 1970s than in the previous decades. From available indications it would appear that many of the policies adopted from the 1970s had not fully achieved their goal. That is, they have not succeeded in reversing the declining trend in the agricultural sector. From a height of about 63 per cent during 1960-68, the share fell to 23 per cent between 1975 and 1984. In fact in the early 1980s the share dropped to a mere 21 per cent. There is also some evidence of absolute decline in the output of major crops in spite of such programs as OFN, RBDAs or ADPs.

Rather than generate employment for the growing labour force, agriculture tended to release labour to other sectors of the economy at a much faster rate than those sectors could absorb it. Consequently, the sector share of the total labour force continued to decline (from about 71 per cent in 1960 to about 52 per cent in 1985). Although, the sectoral growth rates in the non-agricultural sectors were higher than that of agriculture, they could not absorb the labour force at the rate it was being released by the agricultural sectors owing to their very low base. This has certainly compounded the unemployment problem in the country. Agriculture appeared not to have satisfied the supply of raw materials to the economy. Until recently when the domestic industries were forced to source raw materials locally, they were increasingly dependent on import for their raw materials. This can be seen in the cries generated by agro-allied industries clamoring for import licenses for importation of agricultural raw materials. Another indication was the clear collapse of many of these industries due to import restriction. The inability of agriculture to play this role satisfactorily has resulted in slow growth or even retardation of the industrial sector, especially those industries that are dependent on agriculture for raw materials. The failure of agriculture to respond positively to the policies introduced during the period under analysis has been blamed partly on some fundamental constraints associated with the underdeveloped nature of agriculture. Ojo (1989) categorized these constraints into production, marketing, input supply and international economic phenomena. Some production constraints include inadequate or poor quality land resources, labour shortages, inadequate capital investment and poor technology. Most governments that try to remove these problems use inappropriate measures. For example, the small scale farmers who form the bulk of the farming population are usually not properly incorporated into the various schemes intended to influence productivity.

Similarly, adequate resources are not provided to improve the institutional structure consisting of agricultural research, extension services, credit agencies, cooperatives, etc towards supporting small holders in a well guided transformation strategy. Moreover, some macro-economic policies are quite detrimental to the production environment, especially with regards to the export crops. For example, overvaluation of the currency put a ceiling on the Naira earnings of the export crop producers and pegged interest rate tends to benefit the big farmers at the expense of the small holders. Similarly, the minimum 
wage law has the tendency to attract people away from the farm, thus creating labour shortages on the farm. Although government introduced series of reforms into the marketing environment through the marketing boards, the system remained a source of disincentive to the farmers. Even after the 1976/77 reform, the resulting system became large and complex while much of the subsidy meant for farmers was used in financing the complex marketing system. Beside all these, the marketing boards that were geared towards supporting the farmers through prompt supply of inputs and provision of extension service were not well funded. The input supply scheme that was put in place never met more than a small proportion of the farmer's needs. Thus, the majority of the farmers never came in contact with the scheme, a situation that was compounded by the poor distribution system. Finally, some factors generated outside the economic system have serious implications for agricultural performance. One is the regular decline in the prices of primary commodities in the world market. While there have been increased supplies of these commodities over the last decade in some countries e.g. Malaysia (rubber, palm oil) and Cote d'Ivoire (cocoa), Nigeria has lost its competitive position in the production and export of these commodities. The graph below depicts the efficiency level of the sector over time. It gives the true picture of the competitiveness, which cannot yield optimum results.

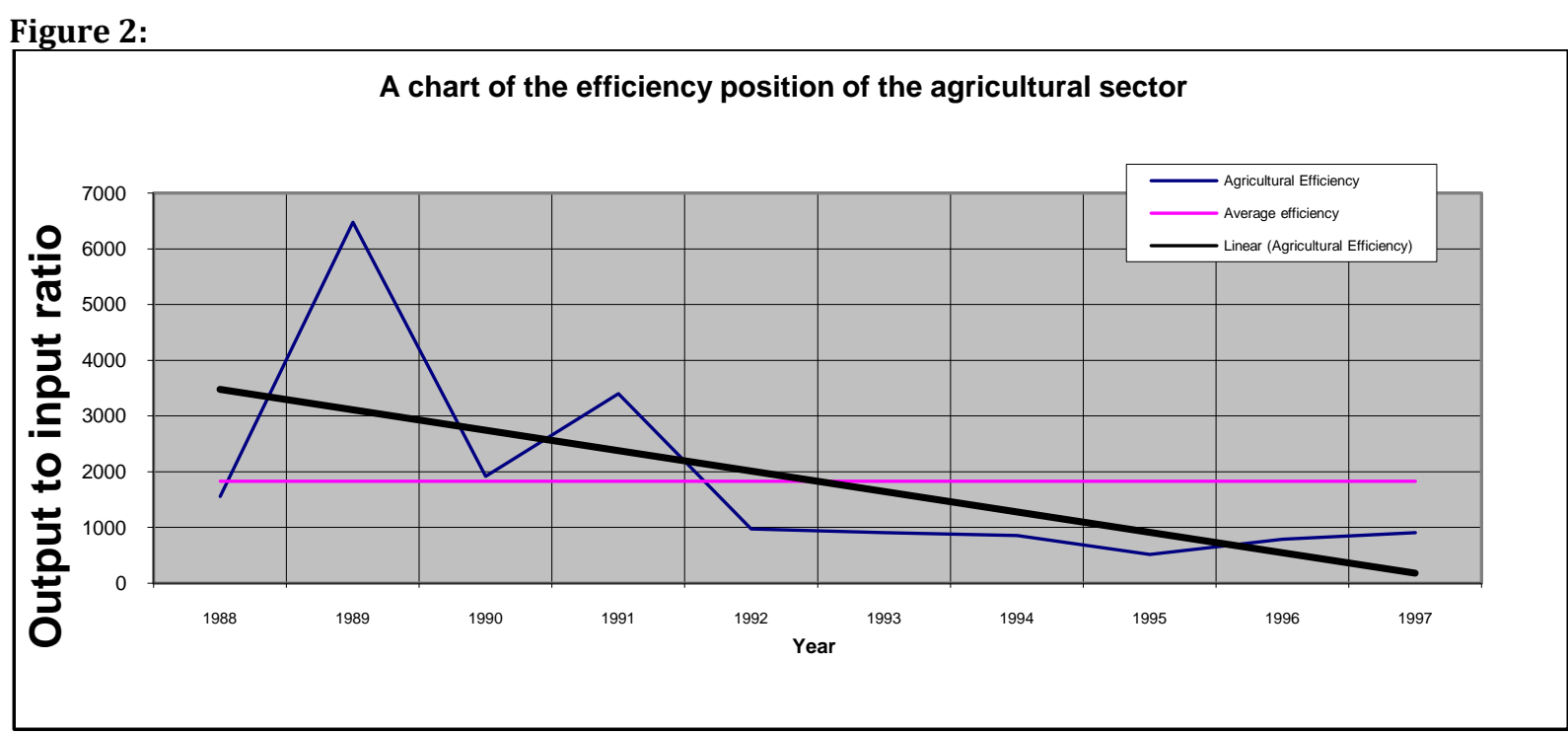

Source: Calculated from Statistical Bulletin and CBN Annual Report, and Statement of Account 2001

The efficiency level peaked during the reforms and started declining afterwards. Though the sector in Nigeria seems to be dominating because of its contribution to GDP, facts from other economies reveal that Nigerian agricultural sector is yet to achieve the desired level of productivity and efficiency. In Cote d'Ivoire, agriculture account for four times exports when compared with Nigeria. See the table 5 below:

Table 5: Agriculture in the economies of Cote d'Ivoire and Nigeria

\begin{tabular}{lllllll}
\hline Country & $\begin{array}{l}\text { Rural population } \\
\text { As \% of } \\
(\mathbf{1 9 9 3 )}\end{array}$ & $\begin{array}{l}\text { Agric } \\
\text { (19) }\end{array}$ & $\begin{array}{l}\text { As } \\
(\mathbf{1 9 9 3 )}\end{array}$ & of GDP & $\begin{array}{l}\text { Agric as \% } \\
\text { Exports }\end{array}$ & $\begin{array}{l}\text { Percentage of } \\
\text { labour force in } \\
\text { Agric (1990) }\end{array}$ \\
\hline Cote d'Ivoire & 58 & 37 & 66.0 & 60 \\
Nigeria & 62 & 34 & 15 & 43 \\
\hline
\end{tabular}

Source: Business Day February $13^{\text {th }} 2003$ Vol. 2 No. 197 pp 25

Also the industrialized countries which demand the bulk of these commodities have increased their domestic production especially of oil seeds and rubber through synthetic technology. Many developing countries, especially in South East Asia have succeeded in diversifying away from primary products into industrial products in spite of the protectionist walls in the industrialized countries. These various problems have to be tackled if the policies and programs implemented in the agricultural sector are to be effective. The fact, that many of the earlier policies were ineffective may be ascribed to the existence and intensity of these problems. Therefore, in order for future policies to have maximum impact, these problems would need to be given serious attention. 
Agriculture within the Structural Adjustment Program: The general objective of agricultural policy under the structural Adjustment Program (SAP) was to invigorate the nation's flagging agricultural economy as a result of past failures through an entirely new philosophy of development. In pursuance of this objective, agriculture has been regarded essentially as private sector business with government seeking to play only supportive role. Measures adopted under the Structural Adjustment Program to enhance agricultural development were as follows:-

a) Interest rates were deregulated. This policy is believed would encourage the voluntary inflow of credit to the agricultural sector which before SAP was enjoying concessionary rates of interest with the resultant unwillingness of banks to significantly lend to the sector;

b) The tariff structure was adjusted to encourage local production and protect agriculture and local industries from unfair international competition;

c) The naira devalued to encourage exports;

d) Marketing Boards for scheduled crops were abolished and individuals were allowed to export their produce and keep the proceeds of their exports in domiciliary accounts. This was aimed at removing the administrative bottlenecks associated with Marketing Boards and to encourage farmers to produce for exports and take advantage of price and other developments in international markets;

e) Importation of a number of food items was banned, including most livestock products, rice, maize, wheat and vegetable oils to encourage local production and protect agriculture and local industries;

f) Subsidies on inputs were reduced following malpractices in their allocation; but a $50 \mathrm{~kg}$ bag of fertilizer which costs the government about N350 is still intended to reach farmers at N4.00, implying a subsidy of about 88.6 per cent. Subsidized land clearing and tractor hiring services are still being provided by many state governments;

g) A number of new institutions were created for agricultural and rural development, among which are the Directorate of Food, Roads and Infrastructure (DFRRI) and the National Directorate of Employment (NDE). They are to create easy access to rural areas to facilitate increased food production, ease the evacuation of farm produce and provide rural infrastructure to support agrobased and cottage enterprises so as to stem rural urban migration;

h) Some existing institutions were reorganized e.g. the River Basin and Rural Development Authorities were directed to dis-engage from direct agricultural production and to concentrate on the provision of water for irrigation of agricultural land and for other purposes;

i) Most publicly owned agricultural enterprises are being privatized or commercialized while the government pays more attention to environmental problems pest, disease, drought, erosion and landslides;

j) Land is to be made available to those who are interested in farming through the National Land Development Authority (NALDA) established in 1990 with a take-off grant of N300 million to acquire at least 50,000 hectares of land in each state of the Federation for agricultural activities;

$k$ ) The government is assisting farmers in the formation of Federation of Farmers' Association of Nigeria. It is hoped that this body would, in future, cater effectively for the welfare of its members and if possible, assist in making the distribution of inputs such as fertilizers to farmers under its umbrella more efficient;

l) The Nigeria Export Import Bank (NEXIM) was established in January 1990 to help encourage exports of the country's agricultural and manufactured products through the provision of pre-and postshipment financing to indigenous export N552.4Million in 1988 to N17.5Million in 1989 and N1,371.0 Million in 1990 before the institution was formally established; and

m) The Government has been sourcing credit from International Financial Institutions for specific agricultural projects. These include the Government/World Bank Grazing Reserve Development and the Nigerian Economic Reconstruction Fund (NERFUND). Under the first project, N41, 440 million has been disbursed to 8,043 small-holder livestock farmers to support their productive activities, 220 boreholes have been drilled to provide water and 24 research projects are being funded in six universities and other higher institutions. Counterpart funding of about N40 Million, in support of the program, is currently outstanding. The second project aims at settling 60 pastoralist families in grazing reserves and developing earth dams and rural roads. At end-1991, 41 families (68.3) per cent were settled and 9 earth dams and $110 \mathrm{~km}$ of roads were built. The sources of NERFUND funds include N100million by the Government and counterpart funding of about $\$ 280$ million from the African Development and the World Banks. About 61 agro-allied and industrial projects, in 16 states, were approved with disbursement of $\$ 4,553,549.00$ made to 13 of these projects by the first quarter of 1991. 


\section{Impact of the Structural Adjustment Program}

Agriculture was expected to play a very significant role in achieving the goals of SAP. It is on this expectation that government assigned specific and prominent functions to agriculture for the attainment of the said goals of the reform. The question is: has the sector succeeded in playing the roles expected of it in achieving the goals of SAP. It is important to bear in mind that SAP did not last, and is a medium term to long term program, which implies the effects would not be felt in the short term. There were indications of some moderate output increase following the introduction of SAP. This is especially so with the export crops which benefited most from the price inducement of the program. For the tree crops, the initial observed response may have resulted from better management and rehabilitation of existing plantation rather than increase in the stock. The graph below presents the picture:

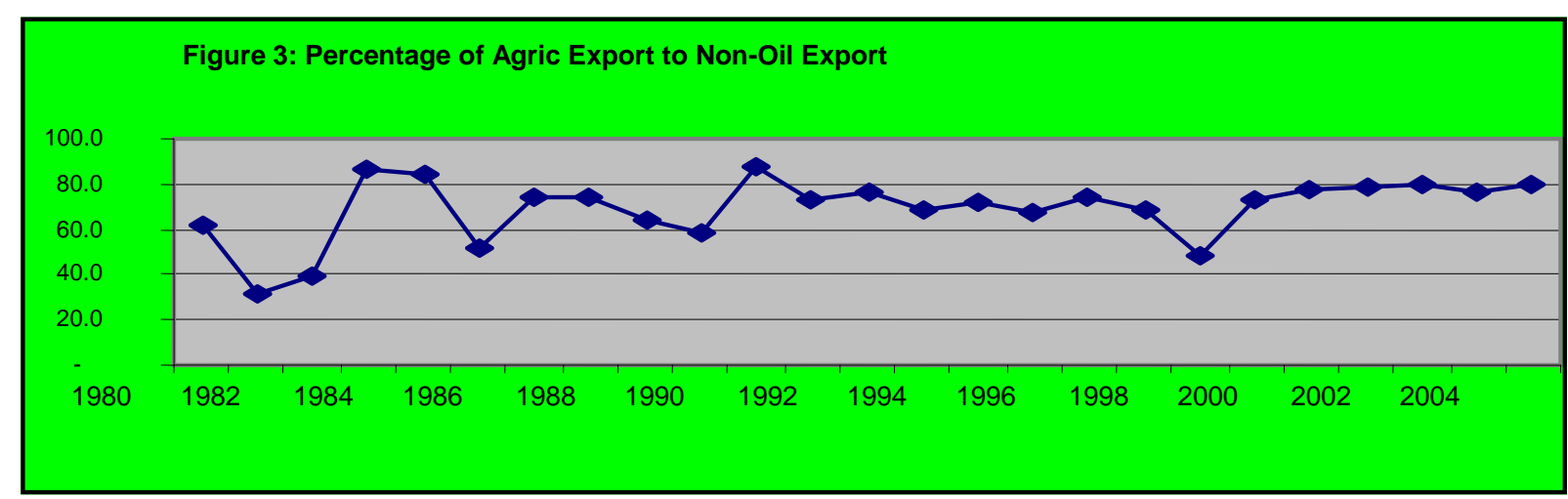

Sources: Statistical Bulletin and CBN Annual Report, and Statement of Account 2004

The percentage of agric export to non oil sector increased from a sharp decline in 1985 to a moderate increase in 1986 through 1987 though with experience of some shocks along the line but the value has remained relatively stable over time. Also, the sector appears to have responded to the reform initiatives as its share in the GDP not only stopped declining but also picked up. This is true even after inflationary adjustment. The graph below shows the trending of agric GDP share over time with relative stability since the inception of the reforms.

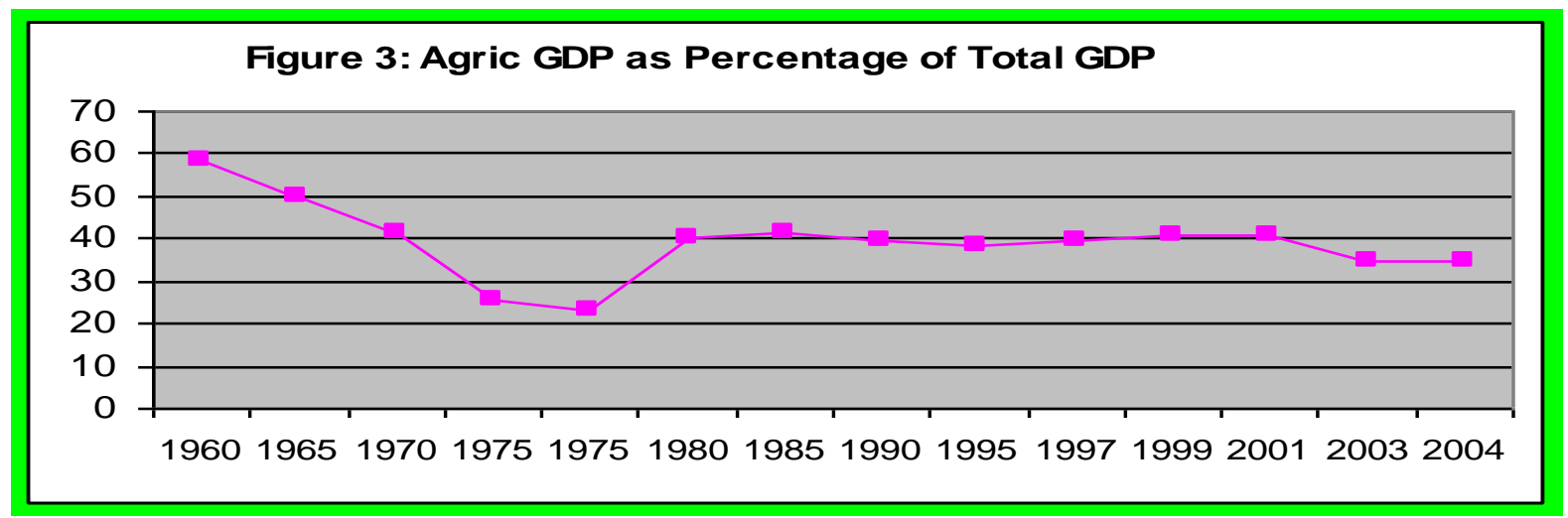

Sources: CBN Statistical bulletin Dec 1998, CBN Annual Report and statement of Accounts Dec 2004

Howbeit, it would appear that the sector is to some extent responding to the challenges posed by the structural adjustment program. The degree of response appears a little slow in the case of output of some of the crops. Since output is a crucial determinant of some other variables such as income, revenues, foreign exchange etc; these variables have also not responded as fast as might be expected.

For the sector to respond much more quickly to the policies of the reform of 1986 and of current date, and serve as an input into the macro model of Nigeria, an understanding of the elasticity of the determinants with respect to output growth in the sector is necessary. 


\section{Conclusion and Recommendations}

It should be noted that major constraints inhibiting private sector participation in the transformation of agricultural production include:- the rapid shift of population from rural to urban areas and the perceptible shift in consumption patterns from local to imported food items - rice, poultry, etc., lack of funds, inadequate processing and storage facilities as well as inefficiencies in input supply and distribution, oil boom, policy inconsistency and decline in political commitment to agricultural and rural development, inadequate incentive framework and pervasive distortions in the macro economy, absence of price support mechanism and pervasive distortions in macroeconomic and sectoral policies including misaligned exchange rates, heavy explicit taxation of agricultural exports. The continued dependence on rain-fed agriculture and the absence of economies of scale and a land tenure system that inhibits the acquisition of land for mechanized farming is a major problem as well as inadequate agricultural extension services and lack of indigenous capacity or technologies responsive to local conditions. Given the dominant role of agriculture in the economy, prospects for food security, supply of Industrial raw materials and overall economic growth are critically dependent on what happens in this sector. Government is expected to provide the following in order to re-launch the sector to limelight:

- Implement a new agricultural and rural development policy aimed at addressing the foregoing constraints;

- Fostering effective linkage with industry to achieve maximum value addition/processing for export;

- Creation of more agricultural and rural employment opportunities to increase the income of farmers and rural dwellers through the modernization of production and creation of an agricultural sector that is responsive to the demands and realities of the Nigerian economy;

- Reverse the trend in import of food, (which stood at 14.5 per cent of total imports at end 2001), through a progressive program for agricultural expansion. Government is committed to reducing the growing food import bill to stem the rising trade imbalance as well as diversify the foreign exchange earnings base of the economy;

- Strive towards food security and generate surplus for the export market;

- Vigorous implementation of the Presidential Initiatives on Cassava, Rice, Vegetable oil, sugar, livestock, tree crops and cereals. Under this initiative, Nigeria hopes to generate as much as N3 billion annually from the export of agricultural products;

- Taking advantage of the various concessionary arrangements within the WTO, EU-ACP, and the AGOA, NEPAD and the huge market in the West African Region sub region;

- 8.Strengthening of agricultural research and revitalization of the agricultural training and streamlining the extension delivery system including the involvement of non-governmental organizations (NGOs) and opinion leaders in extension delivery though capacity building and promotion of improved technologies that are appropriate to the needs of farmers;

- A review of the agricultural input supply and distribution system with a view to developing effective and sustainable private sector-led input supply and distribution system; and

- Promotion of integrated rural development involving agricultural and non-agricultural activities and including the provision of physical infrastructure such as feeder roads, rural water supply, rural communications etc.

\section{References}

Adubi, A. A. \& Okunmadewa, F. (1999): Price, Exchange Rate Volatility and Nigeria's Agricultural Trade Flows: A Dynamic. African Economic Research Consortium (AERC) Paper 89, March.

Aigokhan, B. (1999). Fiscal Federalism and Economic Growth in Nigeria. Nigerian Economic Society Annual Conference, 333-352.

Amassoma, J. D., Nwosa, P. I. \& Ofere, A. F. (2011). The Nexus of Interest Rate Deregulation, Lending Rate and Agricultural Productivity in Nigeria. Current Research Journal of Economic Theory, 3(2), 53 61

Anon, (1987). Fertilizer Procurement and Distribution; Division of the Federal Ministry of Agric., Water Resources and Rural Development, Lagos, Nigeria.

Anon, P. (1989). Fertilizer Use and Management Practices for Crops in Nigeria. Series No 2. Federal Ministry of Agriculture, Water Resources and Rural Development, Lagos, 163

Anyanwu, J. C. (1999). Fiscal Relations among the various Tiers of Government in Nigeria, Nigerian Economic Society Annual Conference, 119-144. 
Business Day February 13 th 2003 Vol. 2 No. 197 pp 25

Central Bank of Nigeria, Annual Report and Statement of Accounts, various issues

European Development Fund (EDF). (2001). Programming Study for Nigeria-Final Synthesis Report No. $11 / 14$.

European Development Fund (EDF). (2001). Programming Study for Nigeria-Poverty Report No. 04/14

Federal Ministry of Finance Abuja. (2000): Nigeria: Targeted Poverty Reduction Background Paper for CG Prepared by Inter-ministerial Technical Committee on Poverty.

Ikhatua, U. J. (2000). The Nigerian Livestock Industry: A Sleeping Giant? Inaugural Lecture presented at the University of Benin, Benin on October 12, 2000.

Iyoha, M. \& Oriakhi, J. (2002). Explaining African Growth Experience: Growth performance in Nigeria" African Economic Research Consortium, Nairobi

Kwanashie, M., Ajilima, I. \& Garba, A. (1998). The Nigerian Economy: Response of Agriculture to Adjustment Policies. African Economic Research Consortium (AERC) Paper 78, March.

National Poverty Eradication Program (NAPEP). (2001). Areas of International Assistance.

Momor, J. (2012): History of Nigeria Agriculture by Sector. Retrieved from http://www.onlinenigeria.com/agriculture/?blurb=481, September 21, 2012.

Njoku, P. C. (2002). Nigerian Agriculture and the Challenges of the 21 ${ }^{\text {st }}$ Century. Journal of Tropical Agriculture, Food, Environment and Extension, 1(1).

Nigeria, S. (2001). Program Study for Nigeria- Regional Integration Development Researchers Network with African Leadership Forum for the National Planning Commission, Federal Republic of Nigeria, Project No. 7 ACP UNI 050, Report No. 13/14 (July).

Ojo, M. O. (1989). An Appraisal of the Socio-Economic Impact of Structural Adjustment Program Policies in Nigeria. CBN Bullion, 13(3 - 4), July/December.

Okonjo-Iweala, N., Soludo, C. C. \& Muhtar, M. (2003). The Debt Trap in Nigeria, Towards a Sustainable Debt Strategy', Eritrea, Africa World Press Inc.

Omofema, O. S. (2007). Arable Farming. Retrieved from http://agriculturepro.blogspot.com, September $21,2012$.

Porter, M. E. (2002). The Global Competitiveness report Centre for International Development the Global Competitiveness Report 2001-2002, Centre for International Development: New York, Oxford University Press.

Ugwu, D. S. \& Kanu, I. O. (2012). Effects of Agricultural Reforms on the Agricultural Sector in Nigeria. Journal of African Studies and Development, 4(2), 51 - 59. 